\title{
CLIMATE CHANGE PROJECTIONS FOR THE UNITED STATES MIDWEST
}

\author{
DONALD J. WUEBBLES* and KATHARINE HAYHOE \\ Department of Atmospheric Sciences, University of Illinois, Urbana-Champaign, 105 S. Gregory \\ St., Urbana, IL 61801 \\ (*Author for correspondence: Tel.: 217-244-1568; Fax: 217-244-4393; \\ E-mail:wuebbles@atmos.uiuc.edu)
}

(Received 28 February 2003; accepted in final form 16 October 2003)

\begin{abstract}
Environmental and societal factors such as air quality, water quality and availability, land use changes and expanding urbanization are already affecting human health and welfare, agriculture, and natural ecosystems in the Midwestern United States. Over this century, these existing stresses will likely be exacerbated by climate changes resulting from human activities. It is essential that policy decisions aimed at preserving the well-being of a region be informed by a good understanding of the region's climate, how climate might change, and the uncertainties inherent in future projections. Recent updates in climate modeling expertise and an expanded view of possible non-intervention emission scenarios have narrowed the range of change that can be expected over the Midwest throughout the next century in some ways, while broadening it in others. In contrast to previous studies, which generally consider a mid-range scenario for future emissions, this study presents the range of change that would result from low to high scenarios for climate change. In this way we account for uncertainties in anthropogenic forcing on climate change in the region and quantify the potential effects of human actions on future climate. This analysis also combines the latest climate model projections with historical records of observed climate over the past century, effectively placing potential changes in extreme event frequencies such as heavy rainfall events and temperature threshold exceedances within the context of observed variability over the past century. The purpose of this study is to provide an updated picture of the potential impacts of climate change on the Midwest to inform the impact assessment and policy development community. From the magnitude of the changes projected by this study, it is clear that these must be included in future policy decisions in order to ensure the successful adaptation and survival of existing human and natural systems in the Midwest.
\end{abstract}

Keywords: Midwest, regional climate change, regional impacts assessment

\section{Introduction}

The Midwest is located in the heart of North America. With large urban centers such as Chicago, Cleveland, Detroit and Indianapolis, the eight states ${ }^{1}$ that make up this region are home to almost 60 million people (USCB 2003). Throughout the Midwest and much of the developed world, emissions of carbon dioxide,

1 Midwest states are those bounded by the Mississippi River to the west and the Ohio River to the south. These include Illinois, Indiana, Iowa, Michigan, Minnesota, Missouri, Ohio and Wisconsin. 
other greenhouse gases (GHGs), aerosols and their precursor species are increasing steadily. Much of this increase is attributed to intensified human activity in agriculture, industry and energy. These sectors are traditional strongholds of the Midwestern economy, which currently produces over $25 \%$ of the total value of U.S. manufactured and agricultural products (USDA 2000; USCB 1999). Led by Illinois, the majority of the states lie in the top 20 in terms of industrial, commercial and residential energy use. Electricity production in these states is heavily dependent on burning coal, which produces the highest amount of carbon per unit energy. In 2002, the Midwest was responsible for emissions of over 400 MTCE, more than $90 \%$ of which were due to fossil fuel use (USEPA 2003).

Increasing GHG emissions are seriously perturbing the radiative forcing the atmosphere, causing global levels of atmospheric carbon dioxide and other greenhouse gases to build up at an unprecedented rate (Ehhalt et al. 2001; Prentice et al. 2001). This build-up enhances the Earth's natural greenhouse effect, and is projected to lead to significant increases in the radiative forcing of the climate system and corresponding increases in global and regional temperatures over the next century (Ramaswamy 2001). The beginning of this increase may already be observed; according to the instrumental temperature record of global mean annual temperature, the 1990s was the warmest decade on record, while 1998 was the warmest year since 1861, the beginning of the instrumental record used by the IPCC (Folland et al. 2001). 1998 was also one of the warmest years on record throughout much of the Midwest (NCDC 2003).

As we enter a new century, the Midwest already faces concerns over water quality and availability, pollution, ecosystem health, expanding urbanization, and a number of other issues. Exacerbating these concerns is the possibility of longterm changes in climate that carry the potential for widespread impacts on natural resources, ecological systems, human health, infrastructure and the economy. To successfully address these concerns, regional policy development and planning focused on mitigation and adaptation to existing stresses must include the uncertainties introduced by future climate change. In order to inform such decisions, this analysis specifically focuses on constraining the range of potential changes in regional climate that impact the Midwest area in three key ways: agriculture and water resources; ecosystems; and human health and welfare.

\section{Data Sources and Methods}

\subsection{HistoricAl DATA}

Historical data were obtained from the database maintained by the Midwestern Regional Climate Center at the Illinois State Water Survey (Kunkel et al. 1998, 1990). This data includes daily observations of maximum and minimum temperature (in degrees Fahrenheit) and daily precipitation (in units of millimeters per day) from 
over 300 stations dating back over a century. These long-term records offer the best view of what climate has been like and how it has already changed. Studies using observed station data in the Midwest have already shown how the length of the frost-free season has increased by as much as two weeks since the beginning of the century, mainly due to earlier dates for the last spring freeze (Kling et al. 2003). These studies have also identified an increase in heavy rainfall events such that these are now twice as frequent as during the early part of the century (Kunkel et al. 1999).

\subsection{EMISSION SCENARIOS}

Forecasts of changes in future climate due to emissions from human activities begin with emission scenarios that represent plausible future conditions under a consistent set of assumptions. The IS92 scenarios (Leggett et al. 1992) have been used in most previous assessments of national and regional climate change. However, these scenarios contain a number of inconsistencies and assumptions that are considered limited in the face of current uncertainty as to how the world will develop over the next century ${ }^{2}$. The more recent SRES scenarios (Special Report on Emission Scenarios, IPCC 2000) have become the standard for climate analyses and have been adopted for the climate analysis presented here. It is important to note that these scenarios represent the possible range for business-as-usual with no specific intervention to reduce emissions in order to slow down or prevent climate change. This analysis considers one scenario from each of the four SRES storylines - A1, A2, B2 and B1 - that describe divergent futures spanning a significant portion of the underlying uncertainties in the main forces driving emissions.

The A1FI scenario is a fossil-intensive scenario lying at the highest end of the range of human-related GHG emissions throughout the next century. In this scenario, a rapid rate of temperature change is driven by a continued dependence on fossil fuels and rapid economic growth throughout the next century. The A2 and B2 scenarios span the middle range of projections and bracket the IS92a scenario on which a number of earlier impact assessments are based. At the upper midrange, A2 represents a very heterogeneous world where economic development is regionally-oriented and economic growth \& technological change are relatively slow. By the end of the century, A2 emissions exceed those of the A1FI 'high' scenario. In the lower mid-range, the emphasis in the B2 scenario is on local solutions to economic, social, and environmental sustainability with less rapid and more diverse technological change. Finally, the B1 scenario, which has the lowest emissions by the end of the century, focuses on global solutions to economic, social

2 For example, IS92 emissions of sulfur and other aerosol precursors were projected to triple by the end of the century despite the fact that they were already being reduced through air quality legislation. Also, IS92 scenarios failed to cover an adequate range of possible futures, in particular tending to under-estimate the results of a non-intervention policy towards climate change. 
and environmental sustainability. Clean, efficient technology is introduced but no specific climate initiatives are taken.

\subsection{Climate model PRojections}

The primary source of future climate projections is general circulation models (GCMs) that incorporate the latest understanding of the physical processes at work in the atmosphere, oceans, and the Earth's surface. Models are constantly being enhanced as our understanding of climate improves and as computational power increases, enabling additional components of the Earth-ocean-atmosphere system to be dynamically linked. Impact studies to date, including the U.S. National Assessment (NAST 2001), have all used the previous generation of flux-corrected GCMs based on either a $\mathrm{CO}_{2}$ doubling scenario or the IS92a scenario. With the exception of Kling et al. (2003), this is the first application of SRES projections specifically to the Midwest, based on models that do not include flux adjustments.

The actual impacts of climate change are often critically dependent on localized features of climate that may not be represented adequately when averaged on the coarse resolution of a typical GCM grid. For example, the enhanced snowfall and moderated temperatures that occur near the shores of the Great Lakes are not well represented characterized at the grid resolution of global models. Ideally, higher-resolution dynamically downscaled GCM projections should be used for detailed impact studies. However, regional climate modeling requires a significant investment of time, computing, and data storage resources, and SRES-based RCM projections are not yet available for the U.S. In presenting the large-scale patterns of change derived from the latest SRES-based GCM projections and comparing these with previous assessments (Tables II and III), we provide the means for reevaluation of past assessments in light of our evolving understanding of future change.

This analysis of future climate possibilities for the Midwest is primarily based on projections for the SRES scenarios A1FI, A2, B2 and B1 from the HadCM3 model, developed at U.K. Meteorological Office's Hadley Centre for Climate Modelling (Gordon et al. 2000; Pope et al. 2000). HadCM3 falls in the middle of the range of climate model sensitivities, with a temperature increase of $3.0^{\circ} \mathrm{C}$ for a doubling of atmospheric $\mathrm{CO}_{2}$ concentrations. In addition, HadCM3 is the only model which has daily temperature and precipitation data available for all four scenarios, as required for analyses of temperature extremes, frost-free season, heavy rainfall events, etc. We also incorporate monthly temperature and precipitation projections corresponding to the SRES A2 and B2 scenarios from the Parallel Climate Model $(\mathrm{PCM})$, a low-sensitivity model $\left(\Delta \mathrm{T}=1.5^{\circ} \mathrm{C}\right.$ for $\left.2 \times \mathrm{CO}_{2}\right)$ developed at the U.S. National Center for Atmospheric Research (Washington et al. 2000). A1FI and B1 projections for the PCM model are in progress but were not available for inclusion in this study (Meehl, Washington, pers. comm.). We first compare $\mathrm{A} 2$ and $\mathrm{B} 2$ temperature and precipitation projections from the two models 
with previous IS92a-based projections (NAST 2001) to assess the expected 'midrange' change for the Midwest over the next century. Within the established context of a mid-range change, we then explore potential changes in temperature, precipitation, and other climate-related variables resulting from HadCM3 A1FI (high) and B1 (low) scenario projections.

\subsection{COMBINING HISTORICAL AND MODEL DATA}

The historical record of climate over the Midwest was combined with GCM projections to place these within the context of regional climate over the last century. We recognize the significant uncertainties inherent to application of GCM data at a regional scale; however, when considered in combination with a detailed historical record, this analysis can provide additional insights regarding the possible range of future change in this region. A gridding program ${ }^{3}$ that averages randomly-spaced geographic locations was used to convert the historical temperature and precipitation records into a uniform grid at the same resolution as model output. Following NAST (2001), we assumed that model biases relative to observed climate over the reference period 1961-1990 were primarily systematic. If due to model limitations, the same biases would be present in simulations of climate over the next century. Although this assumption is not entirely valid, taking the difference between model projections of future and current climate should remove the systematic component of this bias and reduce uncertainty to the level of other uncertainties introduced by differing model parameterizations. In addition, the impact of changes in land cover and local aerosol distributions, which are also important drivers of local and regional scale changes in climate, were not included as projections for these drivers were not available at the level of detail required for regional analyses.

Projected future change was calibrated to the historical record using 19611990 as a reference period. For temperature, the difference between projected future values and model-calculated 1961-1990 seasonal averages were added to the observed seasonal averages for the reference period. Future precipitation was calculated as the percentage change relative to the 1961-1990 seasonal average, allowing for changes in the frequency and intensity of weather systems over the region. Methodologies used to calculate changes in other climate characteristics, such as heavy precipitation events, are discussed in section 4 .

3 The gridding program uses weighted-average interpolation with successive corrections. It is a 2-pass method that generates the long wavelength component, then adds short wavelength detail. Long-term homogeneity issues such as urban heat island are not considered in this data record. However, we do apply a spatial outlier test to individual daily values using the four nearest grid points, eliminating anomalous values and re-calculating the grid (Achtemeier 1987; Barnes 1964). 


\section{TABLE I}

Bias in PCM and HadCM3 calculations of seasonal average maximum temperature and precipitation over the reference period 1961-1990, relative to observed seasonal averages obtained from gridded station data (Kunkel et al. 1998) over the same period.

\begin{tabular}{cccccc}
\hline & \multicolumn{2}{c}{ Temperature $\left({ }^{\circ} \mathrm{C}\right)$} & \multicolumn{2}{c}{ Precipitation $(\%)$} & HadCM3 \\
\cline { 2 - 3 } \cline { 5 - 6 } & PCM & HadCM3 & & PCM & Henn \\
\hline Winter (DJF) & -3 to +2 & +2 over Great Lakes & -20 to +20 & 0 to +80 over western \\
& & -6 to -3 elsewhere & & edge of region \\
Summer (JJA) & -4 to 0 & -4 to -1 & -20 to +40 & -20 to +40 \\
\hline
\end{tabular}

\subsection{INTER-MODEL AND OBSERVATIONAL COMPARISON}

A comparison of observed temperature and precipitation patterns with PCM and HadCM3 calculations over the reference period of 1961-1990 reveals that, despite their relatively coarse resolution, both models adequately capture observed distributions over the Midwest region. Biases in model-derived seasonal temperature range from $-6{ }^{\circ} \mathrm{C}$ to $+2{ }^{\circ} \mathrm{C}$ (Table I), with both PCM and HadCM3 tending to underestimate temperatures towards the western part of the region in summer. In the winter, HadCM3 has a warm bias over the Great Lakes region which may be a result of over-estimating the moderating effect of the lakes due to the coarse model resolution, and a cool bias elsewhere. In contrast, PCM tends to overestimate winter temperatures over the northwestern part of the region, but also exhibits a cool bias elsewhere. In terms of precipitation, both models tend to over-estimate precipitation across much of the region by an average of $20-40 \%$ relative to observed seasonal averages for 1961-1990. In particular, HadCM3 over-estimates winter precipitation over the western (and drier) part of the region by up to $100 \%$. Although these biases are non-trivial, it must be noted that the model calculations on which they were based do not include changes in stratospheric and tropospheric ozone, volcanic activity, or solar radiation over the reference period so some differences are to be expected. As discussed in NAST (2001), these GCM calculations have not been designed to exactly reproduce the climate of the 20th century, but rather to simulate the feedback mechanisms essential to calculating changes in future climate. For this reason, the presence of biases need not significantly impair their ability to project relative (rather than absolute) change.

Model results for the mid-range A2 and B2 scenarios are in fair agreement regarding the seasonal distribution of temperature change. By 2090-2099, the HadCM3 model predicts slightly lower changes in winter temperatures than PCM, perhaps related to its greater tendency to under-estimate winter temperatures (Table II). However, HadCM3 temperature change projections are approximately $1-3{ }^{\circ} \mathrm{C}$ higher for all seasons, as would be expected from a higher-sensitivity model 
TABLE II

Changes in (a) seasonal average maximum temperatures $\left({ }^{\circ} \mathrm{C}\right)$ and (b) seasonal average precipitation (\%) over the Midwest. Change shown for 2090-2099 period relative to modeled 1961-1990 average. Temperature projections from NCAR-PCM model based on the SRES mid-range emission scenarios (A2 and B2) and the HadCM3 model based on the SRES mid-range, high and low emission scenarios (A2 and B2, A1FI and B1) are compared with projections from NAST (2001) based on the IS92a 'business-as-usual' scenario using previous-generation flux-adjusted CGCM1 and HadCM2 models. As changes in precipitation depend more strongly on the model used than on the scenario, changes for all available scenarios are combined to provide one estimate of precipitation change for each model in (b).

(a) 2090-2099 seasonal change in temperature relative to $1961-1990$ average $\left({ }^{\circ} \mathrm{C}\right)$

\begin{tabular}{lccccccc}
\hline & \multicolumn{3}{c}{ This study } & & & & \multicolumn{2}{c}{ NAST (2001) } \\
\cline { 2 - 3 } Model & PCM & HadCM3 & & & & CGCM1 & HadCM2 \\
\hline Scenario & A2/B2 & A2/B2 & A1FI & B1 & IS92a & IS92a \\
Winter (DJF) & $1-3$ & $3-4$ & $6-7$ & $3-4$ & $4-9{ }^{\circ} \mathrm{C}$ & $2-4^{\circ} \mathrm{C}$ \\
Spring MAM) & $3-4$ & $4-5$ & $7-8$ & $4-5$ & & \\
Summer (JJA) & $3-6$ & $5-8$ & $8-11$ & $4-5$ & & $3-5{ }^{\circ} \mathrm{C}$ & $1-2^{\circ} \mathrm{C}$ \\
Autumn (SON) & $3-4$ & $5-6$ & $8-9$ & $5-6$ & & \\
\hline
\end{tabular}

(b) 2090-2099 seasonal change in precipitation relative to 1961-1990 average (\%)

\begin{tabular}{lccccc}
\hline & This study & & \multicolumn{2}{c}{ NAST (2001) } & \\
\cline { 2 - 3 } \cline { 5 - 5 } & PCM & HadCM3 & CGCM1 & HadCM2 \\
\hline Winter (DJF) & 0 to +30 & -5 to +30 & -10 to +40 & 0 to +35 \\
Spring (MAM) & +10 to +40 & 0 to +30 & & \\
Summer (JJA) & -10 to +10 & -30 to 0 & -20 to +30 & +20 to +80 \\
Autumn (SON) & -20 to 0 & -5 to +20 & & \\
\hline
\end{tabular}

(Table II). HadCM3 and PCM projections of precipitation changes over the Midwest by 2090-2099 are in good agreement, showing a net increase for winter and spring, and a net decrease for summer (Table III). Autumn precipitation change is ambiguous, with HadCM3 suggesting increases up to $20 \%$ while PCM projects decreases down to $-20 \%$.

In Tables II \& III, HadCM3 and PCM A2/B2-based projections for 2090-2099 are compared with IS92a-based projections for the same region made by earlier flux-adjusted models (HadCM2 and CGCM1). SRES-based HadCM3 and PCM temperature change, despite being based on a broader range of emissions, tends to lie between the previous range projected by the HadCM2 (low) and CGCM1 (high) models. Both current and earlier models found similar increases in winter precipitation but - contrary to previous projections of increases in summer rainfall up to $80 \%$ - new projections suggest no increase and possibly a decrease in 
TABLE III

Projected change in seasonal average maximum temperature and precipitation for the period 2070-2099 for the PCM and HadCM3 models compared to the range of projections for the SRES A2 and B2 scenarios obtained by seven GCMs (CCSRNIES, CGCM2, CSIRO, ECHAM4, GFDL, HadCM3 and PCM), as given in Ruosteenoja et al. (2003). Values given for PCM and HadCM3 will differ from those in Table 2 since these changes are for a larger region ('central North America', extending from $30^{\circ} \mathrm{N}$ to $50^{\circ} \mathrm{N}$ and $85^{\circ} \mathrm{W}$ to $105^{\circ} \mathrm{W}$ ) and a longer time period (2070-2099 vs. 2090-2099).

\begin{tabular}{lccccccc}
\hline & \multicolumn{2}{c}{ Temperature $\left({ }^{\circ} \mathrm{C}\right)$} & & \multicolumn{2}{c}{ Precipitation $(\%)$} & All \\
\cline { 2 - 3 } & PCM & HadCM3 & All & & PCM & HadCM3 & All \\
\hline Winter (DJF) & $2-2.5$ & $2.5-4$ & $2-7.5$ & 0 to +5 & +6 to +7 & -10 to +15 \\
Spring (MAM) & $2-2.5$ & $2.5-4.5$ & $2-7.5$ & +6 to +7 & +6 to +9 & +3 to +22 \\
Summer (JJA) & $2-3$ & $5-7$ & $2-7$ & +1 to +3 & -10 to -17 & -20 to +17 \\
Autumn (SON) & $2-2.5$ & $4-5.5$ & $2-5.5$ & +6 to +7 & +7 to +10 & -13 to +10 \\
\hline
\end{tabular}

summer rainfall. These new findings need to be taken into account when assessing potential climate change impacts, as shifts in seasonal characteristics, annual cycles and geographical gradients of precipitation can strongly affect soil moisture, water availability, stream and lake levels across the Midwest.

We also compare HadCM3 and PCM projections compared with all the A2/B2based GCM calculations currently available, as summarized in Table IV. Values given in this table will differ from those presented in this study, as this table presents seasonal average results for a square region bounded by $30^{\circ}-50^{\circ} \mathrm{N}$ and $85^{\circ}-105^{\circ} \mathrm{W}$ as given by Ruosteenoja et al. (2003), while this study focuses specifically on the Midwest states. The PCM model tends to project smaller changes in temperature, while HadCM3's projections lie in the mid to high end of the range. Together, these models capture the full range of temperature change in all seasons except winter, where some models project stronger changes in temperature than estimated here. In terms of precipitation, both PCM and HadCM3 tend to lie in the middle of the range, with none of the models projecting changes greater than $\pm 20 \%$ over the region as a whole (Table IV).

\section{Observed and Projected Trends in Climate}

At the global scale, the impact of increased GHG concentrations is often measured by changes in annual global average temperature. Using the SRES scenarios as input, current GCMs estimate global temperature to increase by $1.4{ }^{\circ} \mathrm{C}$ to $5.8{ }^{\circ} \mathrm{C}$ by 2100 . Our uncertainty as to how the world and hence emission trajectories will change in the future accounts for $2.5^{\circ} \mathrm{C}$ of that range, while $1.9^{\circ} \mathrm{C}$ is due to differences between models (Albritton and Meira Filho 2001). 
TABLE IV

Change in monthly-averaged hydrological variables projected by HadCM3 A2 and B2 (mid-range) scenarios in 2090-2095 relative 1961-1990 seasonal average. $\Uparrow, \Downarrow$ indicate a larger $^{1}$ and uniform change over the Midwest region projected by both scenarios; $\uparrow$ indicate a smaller ${ }^{2}$, non-uniform change; while a negligable or a net zero change over the region is indicated by '-'.

\begin{tabular}{|c|c|c|c|c|}
\hline & Winter (DJF) & Spring (MAM) & Summer (JJA) & Autumn (SON) \\
\hline Precipitation & $\uparrow$ & $\Uparrow$ & $\Downarrow$ & $\uparrow$ \\
\hline Evaporation & $\Uparrow$ & $\uparrow$ & - & $\uparrow$ \\
\hline Surface Runoff & $\Uparrow$ & $\Uparrow$ & - & $\uparrow$ \\
\hline Sub-Surface Runoff & - & - & $\Downarrow$ & $\Downarrow$ \\
\hline \multirow[t]{2}{*}{ Soil Moisture } & $\Uparrow$ & $\uparrow$ & $\Downarrow$ & $\Downarrow$ \\
\hline & ${ }^{1}$ Larger chang & ${ }^{2}$ Smaller cha & & \\
\hline Precipitation & $15-30 \%$ & $5-15 \%$ & & \\
\hline Evaporation & $30-80 \%$ & $<30 \%$ & & \\
\hline Surface Runoff & $>100 \%$ & $<100 \%$ & & \\
\hline Sub-Surface Runoff & $20-60 \%$ & $<20 \%$ & & \\
\hline Soil Moisture & $30-60 \%$ & $<30 \%$ & & \\
\hline
\end{tabular}

Regional changes have the potential to far exceed or fall below these values, as they respond to natural variability, topography, geography, and other local conditions. IPCC model compilations conclude that Central North America is likely to exhibit a greater-than-average warming in all four seasons over the next century (Albritton and Meira Filho 2001). Our analysis begins by presenting an update to expected changes in Midwest climate over the next century, placing it within in the context of observed regional climate over the past century.

\subsection{TEMPERATURE TRENDS}

Climatic trends in the Midwest are characterized by high variability on time scales of one to several years relative to long-term trends. It is not uncommon for temperature on a winter's day to vary by as much as $17{ }^{\circ} \mathrm{C}$ from the long term or century-scale mean, and for a summer's day temperature to vary by $8{ }^{\circ} \mathrm{C}$. For a given year, the seasonal temperature anomaly can vary by $4{ }^{\circ} \mathrm{C}$ from the long-term mean (Figure 1(a)).

This high variability often makes it difficult to detect whether long-term trends are occurring. However, since the 1970s temperatures have ranged from near average to somewhat above average in comparison to earlier in the $20^{\text {th }}$ century, particularly in the winter months where two-thirds of the winters over the last 15 years have been above the long-term average (NCDC 2003; Figure 1(a)). In the most recent four years, annual average temperatures have all been $1-2{ }^{\circ} \mathrm{C}$ above 

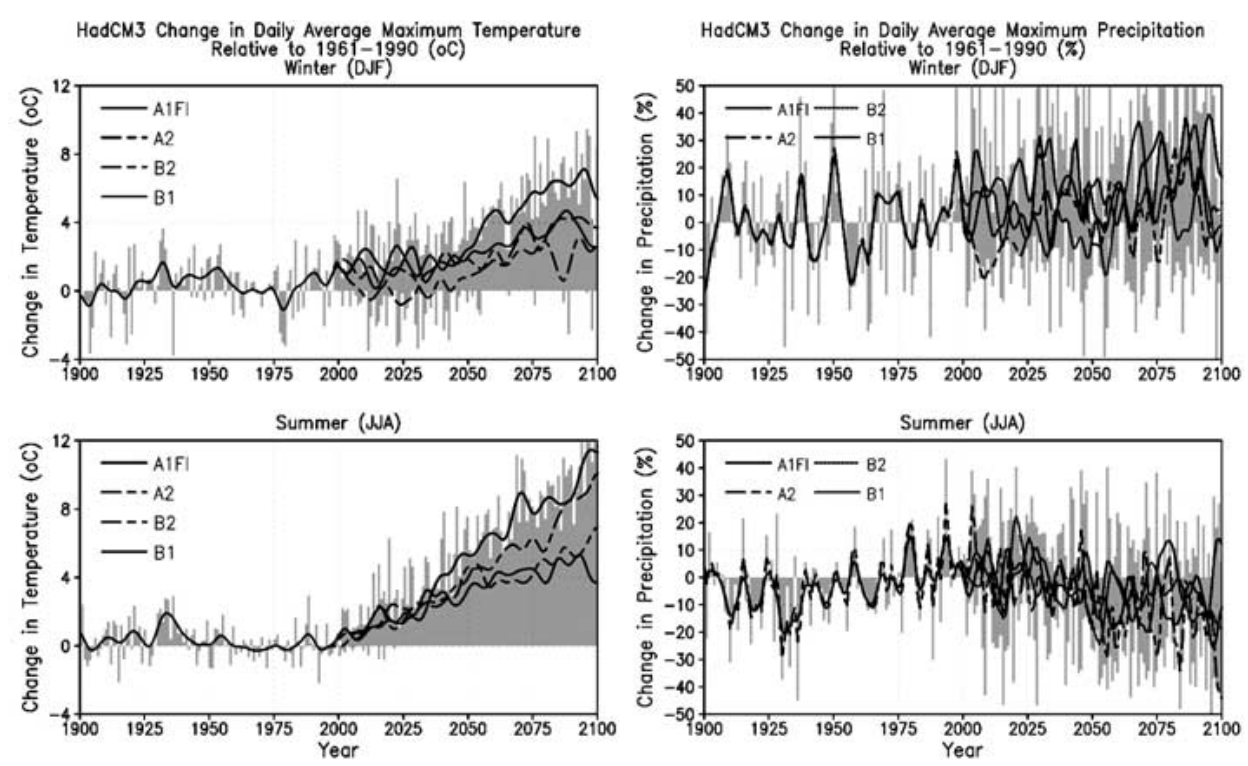

Figure 1. Observed and HadCM3 model-calculated anomalies in (a) daily maximum temperature $\left({ }^{\circ} \mathrm{C}\right)$ and (b) precipitation (\%) relative to the 1961-1990 average for the Midwest. Historical data gridded from over 300 station records is plotted from 1900-2000 (Kunkel et al 1998) while future projections from 2001-2100 are plotted from 2001-2099. Changes in temperature and precipitation are shown for the SRES A1FI (high), A2 (high mid-range), B2 (lower mid-range) and B1 (low) emissions scenarios. Bars show year-to-year variability, while solid lines indicate 10-year running means for temperature and 5-year running means for precipitation.

the long-term average, similar to other warm periods such as the early 1930s and early 1950 s.

Projected changes in climate based on HadCM3 and PCM projections have been determined relative to a baseline, here taken as climate averaged over the period 1961-1990. These results suggest that annual average daily maximum temperatures for the 'mid-range' A2/B2 scenarios could increase $3-6{ }^{\circ} \mathrm{C}$ over the Great Lakes area by the end of the next century, with changes varying by season (Table II). When the HadCM3 A1FI (high) and B1 (low) scenarios are included, this range increases to $3-7^{\circ} \mathrm{C}$ in winter and $4-11^{\circ} \mathrm{C}$ in summer (Figure 1(a)).

Warming is expected to vary across the region (Figure 2(a)). In winter, PCM projections for the A2 scenario averaged over 2070-2099 show a N/S gradient, with the greatest warming at higher latitudes, while HadCM3 shows a greater warming in the westward part of the region. In summer, both models show greatest change over the southern and western part of the region.

\subsection{PRECipitation TRENDS}

Inter-annual variations in precipitation range from $-40 \%$ to $100 \%$ from the mean for a given year. On a seasonal basis, the variation is larger in winter, where precip- 


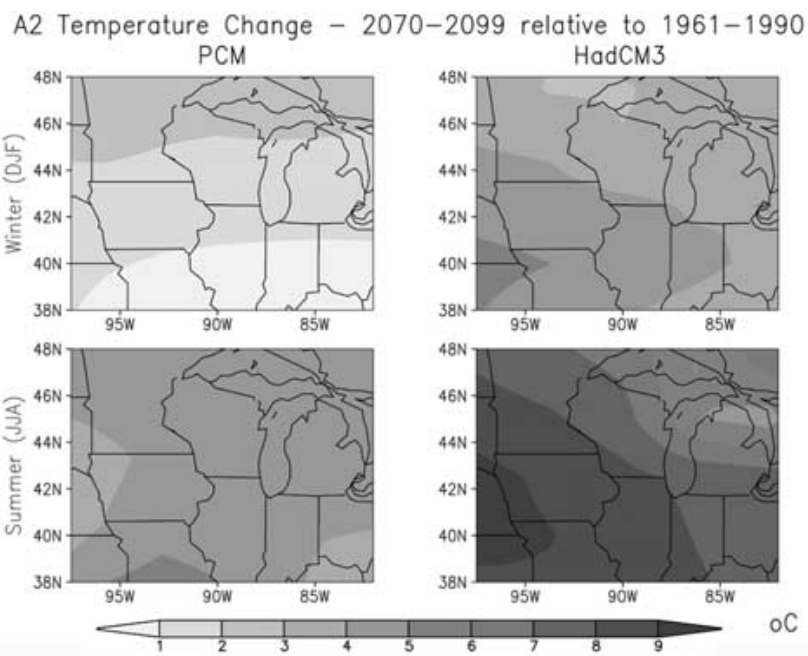

A2 Precipitation Change - 2070-2099 relative to 1961-1990
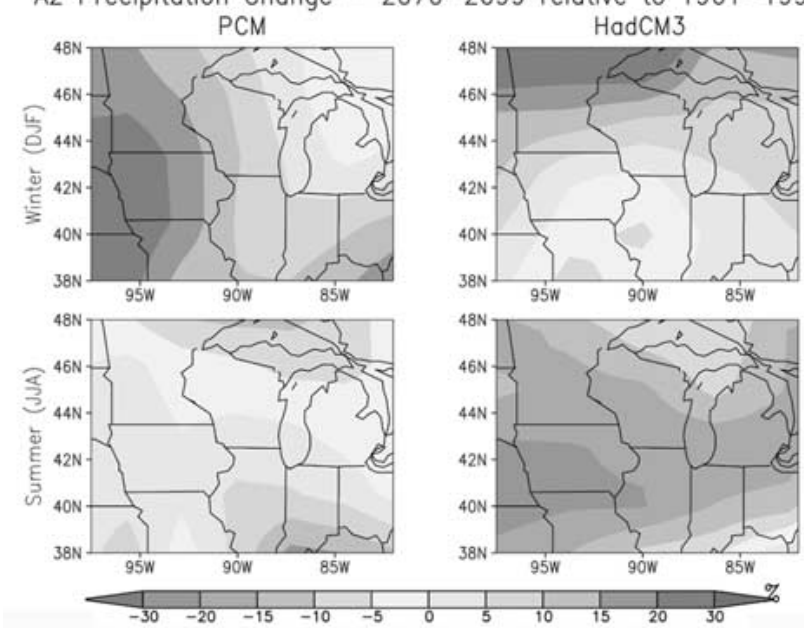

Figure 2. HadCM3 and PCM projections of change in winter and summer (a) average maximum temperature $\left({ }^{\circ} \mathrm{C}\right)$ and (b) precipitation (\%) for 2070-2099 relative to 1961-1990. Results are shown here for the SRES A2 (higher mid-range) scenario. Other scenarios (not shown) also give a similar distribution of change for each model. Smaller projected changes in temperature are shown in yellow while larger changes in temperatures range from orange to red. In contrast, yellow and orange shades indicate a projected decrease in future precipitation, while blue colors signify a projected increase, as shown in the color bars at the bottom of the plots.

itation can range from $-50 \%$ to $+90 \%$ from the mean, whereas summer variations are smaller, at $\pm 40 \%$ (Figure 1(b)). Observed precipitation has generally been above average relative to the previous century since around 1970.

According to the latest model results, average winter precipitation across the region is likely to increase, while summer precipitation remains the same or decreases (Figure 1(b)). Both PCM and HadCM3 project increases in winter average 
precipitation up to $30 \%$ by the end of the century (Table II), with largest increases occurring over northern and western states. The geographical distribution of summer changes in temperature is ambiguous, with PCM projecting slight decreases in the north and similar increases in the south while HadCM3 projects decreases up to $30 \%$ across the region (Figure 2(b)).

Lake effect snows are an important influence in the areas downwind of the Great Lakes. Although these may decrease in the future due to warmer winter air temperatures, Kunkel et al. (2002) found that the other five surface weather conditions were not likely to change significantly, suggesting the possibility of increases in lake effect rain events.

\section{Impacts of Climate Change on the Midwest}

Climate change has the potential to significantly affect agriculture, ecosystems, water resources and human health and welfare throughout the Midwest and Great Lakes regions. All of these areas are already under stress from pressures exerted by our expanding population, growing economy, and continuing urbanization. However, policies to address current concerns must also consider the potential impacts of climate change on each of these areas if they are to succeed in adapting to or mitigating the effects we are having on our environment.

\subsection{Agriculture}

Agricultural production in the Midwest is critically dependent on weather. Rainfall, heat stress, pests, ozone levels, and extreme events such as heavy precipitation, flooding, or drought can seriously affect production, with risks often being higher for smaller farmers and different types of crops (Kling et al. 2003). Previous studies (e.g., NAST 2001; Watson et al. 1998; McCarthy et al. 2001) have suggested that agriculture will largely benefit from the warmer climate and the fertilization effect of increased atmospheric $\mathrm{CO}_{2}$ and that agriculture in the Midwest should largely be able to adapt to the changes in climate. However, these studies also found that while climate change is unlikely to seriously disrupt agriculture in the Midwest, its impacts will be seen through shifting locations for optimal crop production, changes in yield, and the northward movement of pests.

Longer growing seasons and increased production is likely to be a positive result of climate change. Crops sites in the northern states been found to have increased yields under climate change, while those in the southern states of the region may have decreased yields under climate change (Southworth et al. 2000). Assessments for 2025 to 2034 suggest that fruit-growing areas in the Great Lakes region will experience a moderate increase in growing season length and seasonal heat accumulation and a decrease in the frequency of freezing temperatures (Winkler et al. 2002). Changes in temperature and precipitation are expected to shift 
Growing Season in the Midwest States

Observed and Projected Changes, 1900-2100

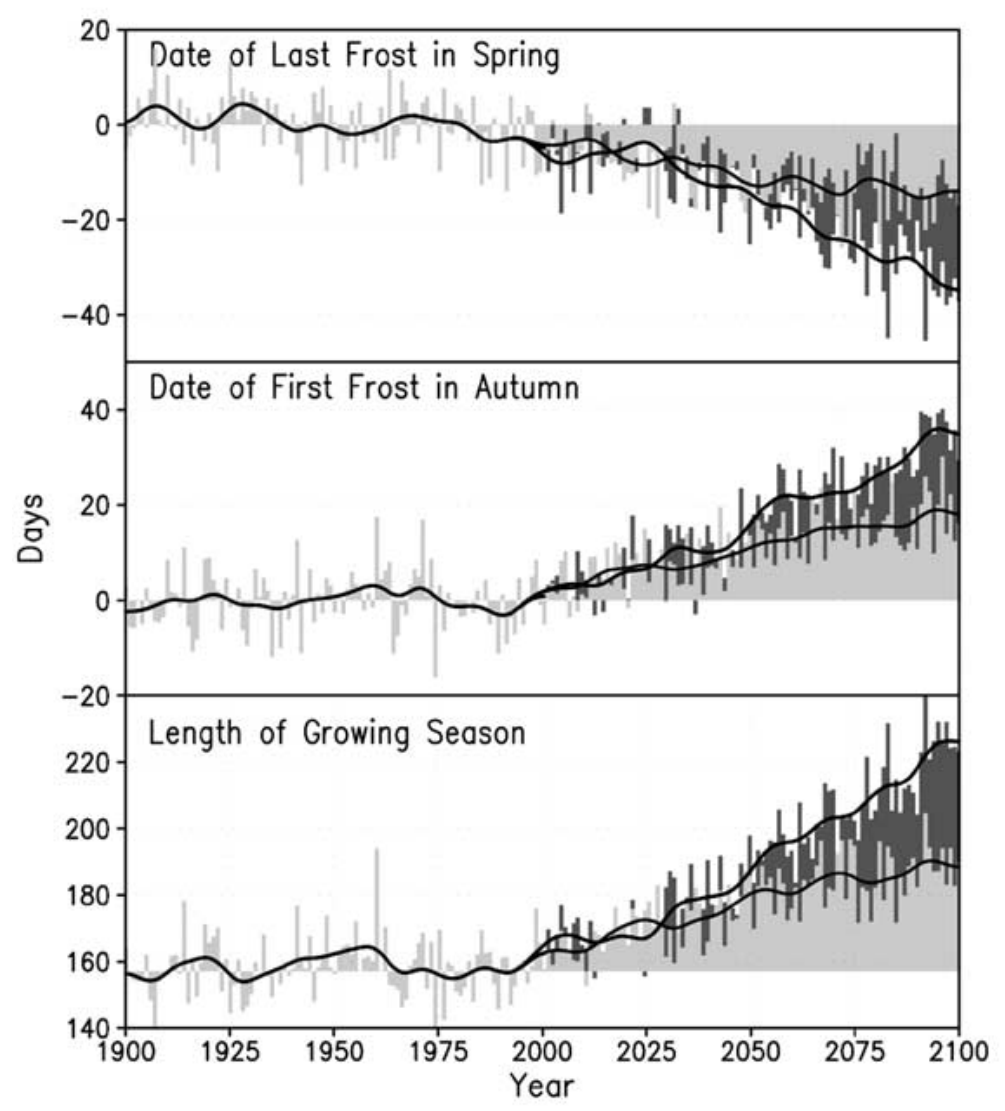

Figure 3. Changes in length of frost-free season and dates of last spring and first autumn frost over the Midwest states. Historical data on the frost-free season is shown from 1900-2000, based on daily minimum temperature records gridded from over 300 stations around the Midwest (Kunkel et al. 1998). HadCM3 projections from 2001-2099, based on daily minimum temperature outputs calibrated to historical growing season lengths over the reference period 1961-1990, are shown in black for the higher A1FI scenario and gray for the lower B1 SRES emission scenario. Bars show year-to-year variability while solid lines indicate 10-year running means.

the most favorable weather conditions northward and eastward benefiting more of Michigan, Minnesota, Wisconsin, and eastern Ontario. However, thin and acidic soils in northern regions may counteract some of the benefits of this shift.

Analysis of historical data shows that the longest frost-free seasons have occurred in the 1990s (Figure 3). Compared to the turn of the century, the frost-free seasons today are about one week longer than at the turn of the century, primarily due to earlier dates for the last spring freeze. HadCM3 A1FI and B1-based projections of daily minimum temperatures, calibrated to the 1961-1990 observed 
frost-free season, suggest that the length of the frost-free season will continue to increase by the end of the century by an additional 4-8 weeks relative to the 19611990 average (Figure 3), as the date of last spring frost becomes earlier by as much as 15-35 days and the date of first autumn frost is pushed back up to 35 days. Longer frost-free seasons generally imply increased agricultural productivity and the possibility for multiple plantings; however, there are many additional factors that will determine the net effect of climate change on agriculture in the Midwest.

Possible decreases in summer rainfall during the critical summer growing periods as well as increased spring rainfall during planting suggested by the results of this study (Table II) will mean lower crop yields. A recent study by Reilly et al. (2003) found that increased losses in yield due to increases in ENSO (El Niño/Southern Oscillation) intensity and frequency could not be completely offset even if the events could be perfectly forecasted. Evapotranspiration in dryland corn is expected to increase in both future periods while water-use efficiency will decrease (Izaurralde et al. 2003). Rainfed lands in the Cornbelt may not require additional irrigation, but there is some concern about increased water-logging during the spring and consequent required increased investment in agricultural drainage (Strzepek et al. 1999). Soil moisture, a key variable for both agriculture and ecosystem welfare, is projected to increase by up to $80 \%$ during winter and spring, but decrease by up to $30 \%$ in summer and autumn (Table IV). This favors crops that rely on water levels being recharged during the winter months; however, crops requiring certain thresholds of summer precipitation and soil moisture levels may come under significant stress.

Warmer temperatures could also mean more heat stroke cases in livestock as well as reducing their appetite and productivity. Livestock performance sensitivity to temperature changes show a decline in weight gain or milk production with higher temperatures (Adams et al. 1999).

Increases in production due to shorter winters, warming temperatures, and longer growing seasons may be counteracted by invasions of pests currently restricted in their northern ranges by temperature (Simberloff 2000). A number of studies (e.g., Mooney 1996) have predicted that increasing temperatures will lead to increasing winter pest survival and increasing numbers of generations per year, thus greatly increasing pest pressures.

Finally, $\mathrm{CO}_{2}$ fertilization may increase crop yield and the water use efficiency, but could be offset by simultaneous increases in ozone levels, thus damaging plants. With future atmospheric $\mathrm{CO}_{2}$ concentrations of $555 \mathrm{ppm}$ (parts per million, by volume), wheat yields increased $60-100 \%$ above current yields across the central and northern areas of the Great Lakes Region by 2050-59 (Southworth et al. 2002b). For the region as a whole, climate changes had an overall beneficial effect, with mean soybean yield increases of 30\% over current levels (Southworth et al. 2002a). The yield-enhancing effects of atmospheric $\mathrm{CO}_{2}$ are an important determinant of potential economic consequences (Adams et al. 1995). 


\subsection{ECOSYSTEMS}

A number of areas in the Midwest are already under significant stress due to human activities and expansion throughout the region. With a large population and the emphasis on farming and other managed land uses throughout the Midwest, many of the natural ecosystems of the region are threatened both directly and indirectly. Although conversion of land from grassland or forest to agriculture or structural development results in direct habitat loss for plant and animal species, landscape fragmentation is a more subtle but equally worrisome problem. As habitats are fragmented and isolated into smaller and smaller refuges, between-site migration rates may decrease, leading to extinction in amphibians (Blaustein et al. 1994) and possibly other species.

Forest ecosystems are expected to experience a shift in composition, including animal species, and location in response to changes in temperature and precipitation patterns across the region. Ultimately, the impact of potential changes in drought or precipitation regimes will depend not only on the predicted scenario of change, but on the type of forest ecosystem and the climatic conditions to which it is currently adapted. Although early model predictions of climate change impacts suggested extensive forest dieback and species migration, more recent analysis suggest that catastrophic dieback will be a local phenomenon, and changes in forest composition will be a relatively gradual process (Hanson and Weltzin 2000). If climate change occurs as rapidly as is predicted, then some species particularly those with heavy seeds may not be able to respond to the rapid changes and local extinctions are expected (Thompson et al. 1998). Forest pests will also move northward with the shift in forest location due to warmer temperatures. The indirect effects of climate change on forests, mediated by alterations of disturbance regimes or the actions of pests and pathogens, may accelerate climate-induced change in forests (Loehle and LeBlanc 1996).

$\mathrm{CO}_{2}$ fertilization will help to spur plant growth, but - as with agricultural crops - this effect may also be offset by the damages due to increased ozone levels. Enhanced carbon fixation during non-stressed periods, driven by the fertilization effect of elevated $\mathrm{CO}_{2}$, may compensate for reduced availability of soil moisture (Hanson and Weltzin 2000). However, changes in ambient levels of ozone and/or acidic deposition can alter basic processes of water, carbon, and nutrient allocation by trees (McLaughlin and Percy 1999). Increased nitrogen levels in the atmosphere may also promote plant growth, but could potentially pollute water resources (Johnson et al. 2000).

Central to ecosystem welfare are the potential impacts of climate change on water distribution and resources throughout the area. We have already seen how precipitation is projected to increase in the winter and spring months, but decrease 
in the summer (Table II; Figure 1(b), 2(b)). As climate warms, evapotranspiration ${ }^{4}$ - the process by which water is returned to the atmosphere - is projected to increase uniformly throughout the year, with the largest increases in winter and spring. However, the changing balance between precipitation and evapotranspiration is highly regionalized. Large areas where P-E changes are negative may occur over the Midwest during winter and summer, and over the Great Lakes during autumn.

Overall, precipitation, evaporation, surface runoff ${ }^{5}$ and soil moisture are all projected to increase during winter and spring (Table IV), suggesting positive impacts for ecosystems which rely on water levels being recharged during the winter months. During summer months, however, precipitation, sub-surface runoff and soil moisture are all project to drop. This indicates the possibility for significant stress on many different types of ecosystems, while some wetland ecosystems may dry up entirely during that time.

In lakes, the duration of winter ice will be shorter, affecting animal species survival and reproduction rates. Earlier ice melt due to warming temperatures will also change the normal stream flow and could possibly add to flooding from spring rainfall (Kling et al. 2003). For those river basins such as Missouri where snow plays an important role in the current climate hydrology, increases in temperature will result in reduced spring snowmelt peaks and increased winter flows (Lettenmaier et al. 1999). Indirect impacts of climate change on ecosystems throughout the Midwest and Great Lakes region include decreases in riverine runoff, less snowfall and snowpack accumulation, higher evapotranspiration, and a reduction in lake levels and connecting channel flows, affecting the quantity and quality of wetland and aquatic habitats and altering the frequency and timing of lake turnover, fish community composition and dynamics (Mortsch and Quinn 1996).

Distribution of fish will change according to the temperature of water; warm water fish, including non-native species, will expand northward, while cold water fish will decrease (Kling et al. 2003). Warmer temperatures will alter lake mixing regimes and availability of fish habitat (Meyer et al. 1999), while annual stream temperatures in the Missouri River and Ohio River basins could increase by $2-5^{\circ} \mathrm{C}$ (Mohseni et al. 1999). Summer stratification in lakes will last longer under warmer conditions, resulting in deep oxygen-depleted areas in lakes where cold water fish will not be able to survive (Lehman 2002). Conditions projected for 2090 in Lake Michigan showed the mean date of stratification beginning as early as 5 April and remaining for 225 days until 20 November. This decreased the estimated mean annual primary production 3\% from the mean base value (Brooks and Zastrow 2002).

\footnotetext{
4 Evaporation in the HadCM3 land-surface model is defined as the total moisture flux from the land surface, or the sum of canopy evaporation, transpiration by vegetation and bare soil, and sublimation from snow. For more details, see Cox et al. (1999).

5 As calculated by the HadCM3 land surface component (Cox et al. 1999), not detailed hydrological impact models.
} 


\subsection{WATER RESOURCES}

As the impervious pavement-covered surfaces of major urban areas and their suburbs expand, covering soil, natural wetlands and floodplains, watershed dynamics are significantly modified. Surface runoff is disrupted ${ }^{6}$, affecting groundwater resources and increasing the potential for flooding (Paul and Meyer 2001). Freshwater resources, drawn from deep aquifers underlying the region, have been plentiful in the past. However, water is currently being withdrawn from many of these at an unsustainable rate, including those surrounding Chicago (Jaffe 2001). In an attempt to remedy this problem, some states have regulations on water resource use while other neighboring states, drawing from some of the same water resources, have none.

Climate change may affect our water resources by lowering lake levels, with their maximums earlier and lower than normal. Lower lake levels would lead to conflicts related to existing and proposed diversions (Changnon and Glantz 1996), as well as increased shipping costs and possible reductions in hydropower (Kling et al. 2003; Cohen and Miller 2001). Despite the recent drop in lake levels, no consistent trend towards lower water levels is evident over the last century. However, maximum lake levels for Lakes Erie and Ontario are rising, with the maximum occurring almost a month earlier than the beginning of the lake level record, 140 years ago (Lenters 2001). Previous hydrological modeling of the potential impact of climate change on future water levels has generally indicated either little change (consistent with what has been observed over the last century) or a decrease in lake levels (Cohen and Miller, 2001; NAST 2001). The latest model projections (Figure 1(b), 2(b)) indicate that annual precipitation over the Midwest may not change significantly. However, evaporation is expected to increase throughout the region due to warmer temperatures (Table IV). During the winter, warmer temperatures decrease the extent and length of ice cover on the lakes. Less ice means more open water and therefore a greater area over which water can evaporate into the atmosphere. Throughout the year, warmer temperatures also increase evaporation rates as the saturation vapor pressure of air increases with temperature. Detailed hydrological model projections for the Great Lakes basin based on the SRES scenarios are not yet available; however, these are currently being run at the Great Lakes Research Laboratory and are expected to become available within the next year (Croley, pers. comm.). In the meantime, projected changes in precipitation, evaporation, and other hydrological variables from SRES-based HadCM3 and PCM calculations appear to support previous findings of drops in lake levels under future change.

Stream \& wetland water levels may also drop, affecting water quality as well as groundwater levels. Together, the coupled effects of decreases in runoff and increases in irrigation could devastate the streams of Illinois and other Midwestern

6 Regardless of soil type, increasing impervious surfaces in a watershed by 10-20\% will cause a $35-50 \%$ increase in surface runoff (Arnold and Gibbons 1996). 
states (Eheart and Tornil 1999). Flooding of rivers from intense storms, encouraging erosion and additional pollution of lakes and wetlands, may be more frequent due to urbanization and drier soils. Changing climate together with changing land use could increase the percentage of precipitation that results in surface runoff by $4 \%$, with $2.5 \%$ being due to climate and $1.5 \%$ due to land use change (Barlage et al. 2002).

\subsection{IMPACTS ON HUMAN HEALTH AND WELFARE}

The impacts of climate and weather on human health and welfare is a growing concern, through both weather-related damages and deaths from extreme events and interactions between heat, air pollution, water quality, and health. It is likely that climate change will exacerbate many of these concerns, changing the frequency of heat waves and heavy rainfall events, improving conditions for the spread of vectorborne diseases, and increasing formation rates of air pollutants in urban areas. On the other hand, climate change may also decrease the duration and intensity of cold spells, alleviating associated illnesses, deaths, and damages.

Among the potentially dangerous risks that climate change will pose on human health include the interactions of temperature, air pollution and human mortality. Air pollution is thought to increase the susceptibility of weaker members of the population, particularly those with respiratory diseases (Bernard et al. 2001), to extreme heat events such as the 1995 heat wave in Chicago that claimed over 700 lives (Changnon et al. 1996). In the future, model studies suggest that southwesterly air flow over the region, which correlates with high ozone levels at the present time, may become more frequent and lead to decreased air quality and a possible increase in the reported incidence of respiratory disease (Sousounis et al. 2002).

If average temperatures are expected to increase in the future, it is likely that extreme temperatures will also change. From 1960-1996, DeGaetano and Allen (2002) found significant increases in warm temperature exceedances at nearly onethird of the stations examined. Analogous trends were found for cold temperature extremes during the same period. In the future, it is likely that there will be an increase in high temperatures and a decrease in extreme low temperatures (e.g., Easterling et al. 2000; Meehl et al. 2000a, b). Heat related illnesses, such as heat stroke, would become more common in the summer months, while the number of cold induced illnesses will decline (Martens 1998). However, a strong association of the temperature-mortality relation with latitude has been identified by Curriero et al. (2002), with a greater effect of colder temperatures on mortality risk in more southern cities and warmer temperatures in more northern cities such as those in the Midwest. Models of weather-mortality relationships indicate that populations in northeastern and Midwestern U.S. cities are likely to experience the greatest number of illnesses and deaths in response to changes in summer temperature (McGeehin and Mirabelli 2001). A tentative climatic comparison also suggests that heat waves are becoming more frequent in the Midwestern and eastern parts of 
the nation (Robinson 2001), although Karl and Knight (1997) found no statistically significant trend in Midwestern heat waves from 1948-1995.

Based on an analysis of historical data over the past century from over 300 stations throughout the Midwest, the high frequency of extreme heat occurring in the 1930s has no comparable multi-year period occurring elsewhere in the time series, although 1988 was characterized by very frequent heat waves, including one in Chicago that was directly or indirectly responsible for over 200 deaths (Figure 1(a)). Over the last 100 years, average daily maximum temperatures over the Midwest exceeded $32^{\circ} \mathrm{C}$ anywhere from 5 to 25 times per year. However, temperatures rarely exceeded the $36^{\circ} \mathrm{C}$ threshold except during the 1930s and 1990s, with a maximum exceedance of 8 times in 1999. In the future, similar conditions to those experienced in the 1990s are projected to hold through the next several decades. However, beginning around 2030, HadCM3 projections based on both the SRES A1FI and B1 scenarios suggest that the number of threshold exceedances may rise sharply. By the end of the century, temperatures are projected to exceed $32{ }^{\circ} \mathrm{C}$ anywhere from 20 to 50 times per year, with a corresponding increase in the frequency of multi-day heat waves. This implies significant increases in heat-related illnesses and mortality rates.

Cold temperatures in the Midwest are also related to human health issues. In terms of historical patterns, cold waves occurred frequently throughout the early part of the $20^{\text {th }}$ century as well as during the late 1970 s and early 1980s. In the 1990s, however, most years saw a below-average number of cold waves. The number of days below $0{ }^{\circ} \mathrm{C}$ has been decreasing steadily since the mid 1980s from their long-term average of 145 days per year. By the end of the century, there may only be an average of 75 to 110 days that reach below $0{ }^{\circ} \mathrm{C}$, while less than 10 days per year may fall below $-15^{\circ} \mathrm{C}$. This suggests a significant reduction in coldrelated illnesses, deaths and damages. However, such a change in climate would likely have an adverse impact on winter kill-off of pests affecting agriculture and ecosystems, and could lead to increased health-related concerns if populations of mosquitoes and other disease carriers grow. Whether major health risks due to malaria or other diseases could result from such pests is still unclear and requires additional study.

Survival and greater reproduction of disease vectors such as ticks and mosquitoes will be more likely with increases in temperatures and longer periods of sustained or heavy rainfall, while drier periods and/or land use changes that drain wetlands and reduce other vector habitats could reduce favorable breeding locations. Specific increases in incidence have been noted for vector-borne diseases, in addition to pulmonary findings, cardiovascular morbidity, neurological diseases, and occupational diseases (Yoganathan 2001). The extreme weather conditions accompanying long-term climate change may also be contributing to the spread of West Nile virus in the United States (Epstein 2001). Current evidence suggests that inter-annual and inter-decadal climate variability have a direct influence on the epidemiology of vector-borne diseases (Githeko et al. 2000). 
Financial losses associated with extreme events such as tornadoes, hurricanes, storms and floods are often associated with weather. In terms of past trends in losses, in reviewing damages from a number of extremes including flooding, hail, hurricanes, tornadoes, and severe thunderstorms, Chagnon (2003) found that flooding was the only extreme to exhibit a net upward trend in adjusted losses from 1950-1997. Other studies have shown that growth in total weather-related damages over the past few decades is related to both increases in heavy precipitation events and societal factors, including population growth and increases in per capita wealth (Pielke and Downton 2000). Chagnon and Chagnon (1998) further divided these factors by concluding that trends in losses under $\$ 100$ were primarily related to population growth, while losses over $\$ 100$ were related to both population and changing weather conditions. In terms of future change, Choi and Fisher (2003) found that a $1 \%$ increase in annual precipitation could enlarge catastrophe loss by as much as $2.8 \%$, with losses increasing primarily due to inflation, population growth and per capita increase in wealth.

A number of studies have documented increases in heavy precipitation across the U.S., with significant increases since the 1920s in the Midwest (Kunkel 2003b; Angel and Huff 1997) that are likely due to spatial \& temporal variations in sea surface temperatures (Kunkel 2003a). Figure 4 shows a significant increase in frequency of 24-hr and 7-day heavy rainfall events over the past century. In particular, frequencies of 24-hr events have almost doubled since the early 1900s, although it must be noted 1980s/1990s are actually very similar to late 1800s (Kunkel 2003b). It is likely that these increases in heavy rainfall events have contributed to increases in total damage from precipitation and floods from 1932-1997 observed by Pielke and Downton (2000) and 1950-1997 (Chagnon 2003).

Short-lived extreme events such as storms and tornadoes are difficult to predict and how the frequency of these events will change in the future is still subject to major uncertainties. However, a number of studies have suggested that heavy rainfall events over the U.S. will increase due to increasing water vapor in the atmosphere coupled with atmospheric destabilization (Easterling et al. 2000; Meehl et al. 2000; Kunkel 2003b). In fact, Trenberth (1999) argues that increases in heavy precipitation events should be a primary manifestation of climate change due to increased atmospheric moisture content. Possible adaptations to change include land use planning and forward-looking infrastructure design in order to avoid increased damages (Cohen and Miller 2001).

As shown in Figure 4, the frequency of heavy precipitation events in the Midwest is also projected to increase. Using the historical record to determine the threshold for defining a heavy precipitation event, HadCM3 heavy precipitation frequencies calculated from daily precipitation data for the A2/B2 scenarios were adjusted to match observed frequencies over the reference period 1961-1990. Daily precipitation projections for the period 2000-2099 were then analyzed to identify events that exceeded the model-calculated historical threshold, which had been calibrated to match observed frequencies. Based on this analysis, both 24-hr and 


\section{Frequency of Heavy Precipitation Events in the Great Lakes Region}

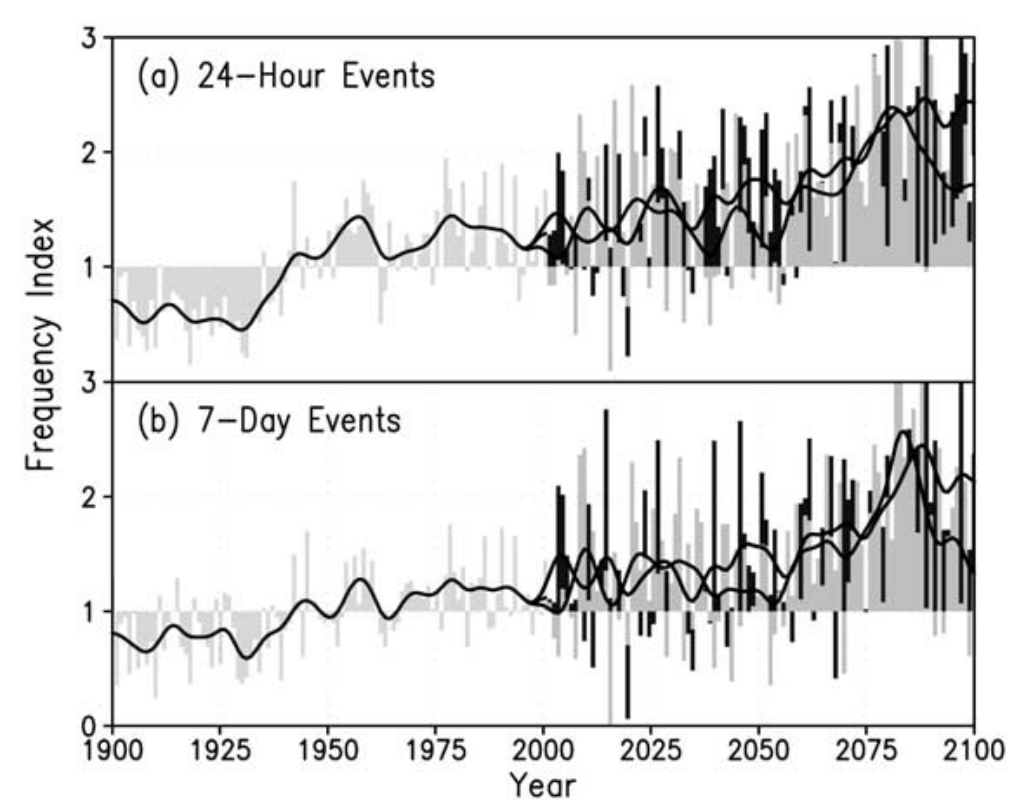

Figure 4. Analysis of historical observed (1900-2000) and HadCM3 mid-range A2 (dark) and B2 (light) projections (2001-2099) shows that both (a) 24-hour and (b) 7-day heavy precipitation events are becoming more frequent in the region. Frequency of historical events was determined by locating the 101 largest events from 1900 to 2000, such that the average was one event per year. In some years, this meant that were no events in certain areas while in other years there could be multiple events. The events were then averaged over the entire Midwest region and plotted according to the year in which they occurred. Frequency of future events was determined by counting the number of model-projected events based on model daily precipitation output that lay within the range of the 101 historical events previously located. The model event threshold was then normalized by the difference between modeled vs. observed historical event frequencies, and the number of future events exceeding the normalized threshold calculated. Bars show the yearly averages while the solid lines indicate the 10-year running mean. Results from two different climate scenarios show similar trends of frequencies remaining well above average for the next few decades and doubling by the end of the century.

7-day heavy rainfall events are projected to double (again) by the end of the next century. Coupled with model projections of little net change in annual average precipitation (although with shifting seasonal precipitation patterns), this suggests that more rain may fall in extreme events, leaving drier periods between the events and possibly increasing the risk of drought as well.

Increased heavy precipitation will increase the risk for flood damage, with Pielke and Downton (2000) finding that flood damage is most closely related the number of 2-day heavy rainfall events and the number of wet days. Additional support for the connection between climate change and flood frequencies is provided by 

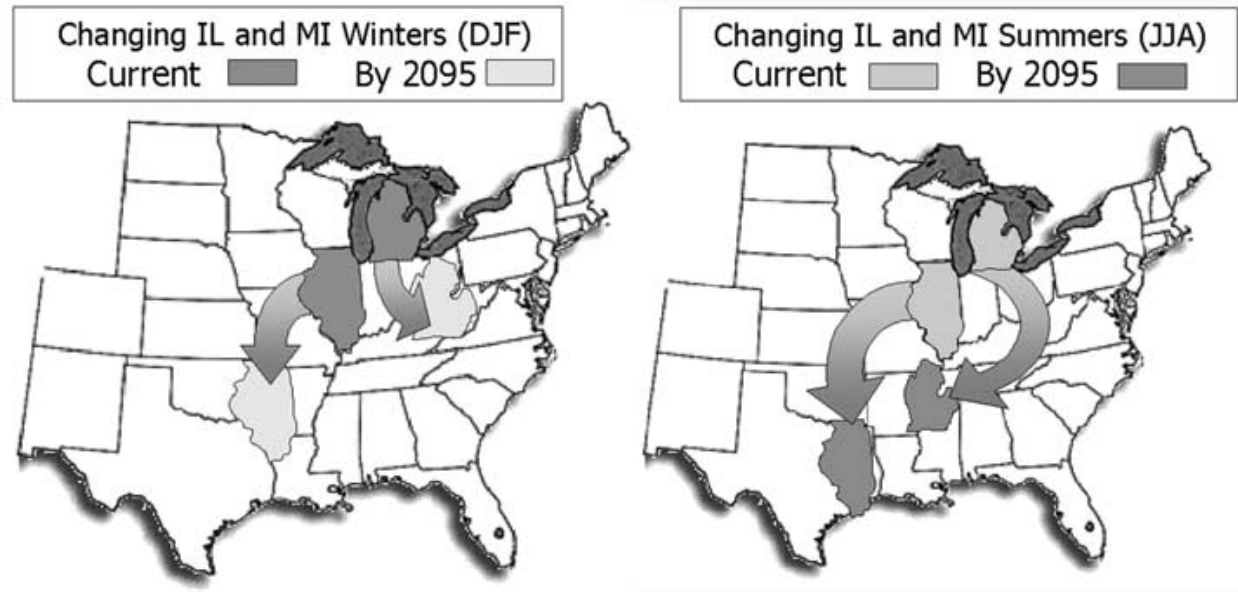

Figure 5. Virtual migration of Illinois and Michigan winters (left) and summers (right). Migration pathway was estimated by comparing current-day winter and summer climatologies throughout the U.S., in terms of average temperature and precipitation, with projected future conditions for IL and MI. Future seasonal average conditions were based on HadCM3 and PCM A2 (higher mid-range) temperature and precipitation projections for 2095 relative to 1961-1990 observed climate.

palaeoflood records reconstructed from the Upper Mississippi and Lower Colorado River systems. These records show that small changes in climate - on the order of $1-2{ }^{\circ} \mathrm{C}$ and a $10-20 \%$ in precipitation, well within the project ranges in Table II - resulted in important changes in the magnitude and recurrence frequencies of extreme floods in the region (Knox and Kundzewicz 1997; Knox 1993).

With heavy rainstorms, waterborne diseases will pose a higher risk to human health. Weather disaster effects will increase in number and magnitude, and both noninfectious and infectious diseases may flourish (Yoganathan 2001). Waterborne disease outbreaks due to surface water contamination showed the strongest association with extreme precipitation during the month of the outbreak, while a 2-month lag applied to groundwater contamination events (Curriero et al. 2001).

\subsection{Migrating Climates}

A helpful indicator of the projected climate effects is a spatial analogue which estimates where selected states will have 'moved' over the next century relative to current temperature and precipitation characteristics. Such analogues have previously been used to illustrate movement of agricultural areas such as the Corn Belt and the Canadian Prairies (Newman 1980; Parry and Carter 1989), as well as the state of Illinois (NAST 2001). Figure 5 illustrates the virtual locations of Michigan and Illinois summers and winters in 2095, according to HadCM3 and PCM results based on the A2/B2 mid-range scenarios.

In terms of temperature and precipitation data, the change in winter climate over the next few decades is ambiguous. However, by 2095 a typical winter cli- 
mate in the state of Illinois can be expected to resemble current-day Oklahoma, while Michigan will have virtually moved to Ohio. In 2030, IL summers will also resemble those of Oklahoma or Arkansas in terms of average temperature and precipitation. However, by the end of the century the IL summer climate will be closer to that of east Texas. MI summer weather could be similar to that of Ohio in a few decades, while by the end of the century MI summers will resemble those of southern Missouri and northern Arkansas today. While highly illustrative, it is important to recognize that such analyses are limited to average conditions and do not consider the extent of variability in the projected climate changes, nor the differences in topographical features from state to state. For example, even if the climate of Michigan does become more like that of Arkansas, it will still be surrounded by the Great Lakes, recreational use of which may increase under a warmer climate. Conversely, if Illinois were to virtually move to NE Texas, it is unlikely that it would experience the severe weather patterns typical of that region, as these are determined largely by the geographical position of Texas in the North American continent. In addition, latitude-dependent conditions such as day length that affect plant development and species migrations would remain unchanged.

\section{Summary}

The Midwestern environment is already under pressure from expanding human development. Contributing to existing pressures is the possibility of climate change. Indeed, changes in climate have already been demonstrated over the past century through warmer winters, shorter ice-free seasons, longer growing seasons, and increases in heavy rainfall events. To succeed in their intended goal, it is essential for impact assessments to consider the full range of potential change in planning for the future. To this end, the intention of this analysis was to provide the impact assessment community with updated model projections based on the latest SRES emission scenarios from both low sensitivity (PCM) and mid/high sensitivity (HadCM3) GCMs for temperature, precipitation, and a number of other climaterelated variables for the Midwest region. In contrast to previous studies, which have generally only considered a mid-range scenario for future emissions, this study includes both low and high scenarios for climate change in order to account for uncertainties in how human activities may affect future climate. In addition, through consideration of the historical climate record for the Midwest, this study is able to much more effectively consider potential changes in the frequency of extreme events such as heavy rainfall and temperature threshold exceedances.

Combining these model projections for the Midwest with the historical observed climate record over the past century, we conclude that:

- By the end of the century, annual average daily maximum temperatures in the Midwest may have increased anywhere from $2-9{ }^{\circ} \mathrm{C}$. This range depends not only on climate sensitivity, but also on the emissions trajectory followed. 
While this range in projected temperature is similar to past studies based solely on the IS92a emissions scenario (NAST 2001), this range now represents both differences in modeled climate sensitivity as well as the full extent of the SRES emission scenarios.

- In contrast to observed increases in winter temperatures over past decades, temperature increases by the end of the next century are projected to be larger for summer and smaller for winter.

- Precipitation is projected to increase by up to $30 \%$ in the winter, while summer precipitation may remain constant or decrease slightly. Results for winter confirm projections made by previous studies, while summer change is lower than previously thought (NAST 2001).

- Frost-free seasons have been lengthening over the last few decades, and are projected to continue to increase over the next century by as much as $4-8$ weeks.

- Hydrological variables, including precipitation, evaporation, runoff and soil moisture, are expected to increase throughout the region in winter and spring, but decrease in summer.

- By 2090, the region may see 20 to 50 more days where temperature exceeds $32{ }^{\circ} \mathrm{C}$ than found under current climate conditions and 40 to 75 less days where temperature falls below freezing.

- The frequency of heavy precipitation events has already increased over the past century, and is projected to double by the end of the next century.

- Temperature and precipitation changes will strongly alter our regional climate. For example, by 2090, an Illinois summer could be more like that currently in eastern Texas, while winters may be more like Oklahoma today.

Although significant uncertainty still remains regarding the exact magnitude of the changes that may occur, it is likely that the Midwest climate over the next century will differ significantly from what we have been accustomed to over the past century. As such, the potential for change should not be taken lightly. In particular, the potential for climate change to interact with and strengthen existing stresses within the region must be seriously considered when making policy decisions that will affect the future environment, economy and welfare of the U.S. Midwest.

\section{Acknowledgements}

This research was supported in part by the Illinois-Indiana Sea Grant program and the Office of the Vice Chancellor of Research at the University of Illinois. Ken Kunkel from the Illinois State Water Survey provided access to historical data and other valuable assistance. Thanks to David Viner and Michael Wehner who made the GCM data used in this study available to us. We also extend our thanks to the anonymous referees for their helpful comments, and to Erin Riepe for assistance with revisions. 


\section{References}

Achtemeier, G.L.: 1987, 'On the concept of varying influence radii for a successive corrections objective analysis', Mon. Wea. Rev. 115, 1760-1772.

Angel, J.R. and Huff, F.A.: 1997, 'Changes in heavy rainfall in Midwestern United States', J. Water Res., Planning \& Manag. 123, 246-249.

Adams, R.M, Fleming, R.A., Chang, C.C., McCarl, B.A. and Rosenzweig, C.: 1995, 'Reassessment of the economic-effects of global climate-change on US agriculture', Climatic Change 30, 147167.

Adams, R.M., Chen, C.C., McCarl, B.A. and Weiher, R.F.: 1999, 'The economic consequences of ENSO events for agriculture', Climate Res. 13, 165-172.

Albritton, D. and Meira Filho, L.G.: 2001, Climate Change 2001: The Scientific Basis - Technical Summary, Cambridge, U.K., Cambridge University Press, 63 pp.

Arnold, C.L. and Gibbons, C.J.: 1996, 'Impervious surface coverage: The emergence of a key environmental condition', Am. Plan. Ass. J. 62, 243-258.

Barlage, M.J., Richards, P.L., Sousounis, P.J. and Brenner, A.J.: 2002, 'Impacts of climate change and land use change on runoff from a Great Lakes watershed', J. Great Lakes Res. 28, 568-582.

Barnes, S.L.: 1964, 'A technique for maximizing details in numerical weather map analysis', J. App. Met. 3, 396-409.

Bernard, S.M., Samet, J.M., Grambsch, A. and Ebi, K.L.: 2001, 'The potential impacts of climate variability and change on air pollution-related health effects in the United States', Envir. Health Persp. 109, 199-209.

Blaustein, A.R., Wake, D.B. and Sousa, W.P.: 1994, 'Amphibian declines: Judging stability, persistence, and susceptibility of populations to local and global extinctions', Conservation Biol. 8 , $60-71$.

Brooks, A.S. and Zastrow, J.C.: 2002, 'The potential influence of climate change on offshore primary production in Lake Michigan', J. Great Lakes Res. 28, 597-607.

Chagnon, S.A.: 2003, 'Shifting economic impacts from weather extremes in the United States: A result of societal changes, not global warming', Natural Hazards 29, 273-290.

Chagnon, D. and Chagnon, S.A.: 1998, 'Evaluation of weather catastrophe data for use in climate change investigations', Climatic Change 38, 435-445.

Changnon, S.A. and Glantz, M.H.: 1996, 'The Great Lakes diversion at Chicago and its implications for climate change', Climatic Change 32, 199-214.

Chagnon, S.A., Kunkel, K.E. and Reinke, B.C.: 1996, 'Impacts and responses to the 1995 heat wave: A call to action', Bull. Amer. Meteor. Soc. 77, 1497-1506.

Choi, O. and Fisher, A.: 2003, 'The impacts of socioeconomic development and climate change on severe weather catastrophe losses: Mid-Atlantic Region (MAR) and the US', Climatic Change 58, 149-170.

Cohen, S. and Miller, K.: 2001, 'North America', in J. McCarthy, O. Canziani, N. Leary, D. Dokken and K. White (eds.), Climate Change 2001: Impacts, Adaptation, and Vulnerability, Cambridge, UK, Cambridge University Press, pp. 735-800.

Covich, A.P., Fritz, S.C., Lamb, P.J., Marzolf, R.D., Matthews, W.J., Poiani, K.A., Prepas, E.E., Richman, M.B. and Winter, T.C.: 1997, 'Potential effects of climate change on aquatic ecosystems of the Great Plains of North America', Hydrol. Proc. 11, 993-1021.

Cox, P.M., Betts, R.A., Bunton, C.B., Essery, R.L.H., Rowntree, P.R. and Smith, J.: 1999, 'The impact of new land surface physics on the GCM simulation of climate and climate sensitivity', Clim. Dyn. 15, 183-203.

Croley, T.E. and Luukkonen, C.L.: 2003, 'Potential effects of climate change on ground water in Lansing, Michigan', J. Am. Water Res. Assn. 39, 149-163.

Curriero, F.C., Heiner, K.S., Samet, J.M., Zeger, S.L., Strug, L. and Patz, J.A.: 2002, 'Temperature and mortality in 11 cities of the eastern United States', Amer. J. Epidemiol. 155, 80-87. 
Curriero, F.C., Patz, J.A., Rose, J.B. and Lele, S.: 2001, 'The association between extreme precipitation and waterborne disease outbreaks in the United States, 1948-1994', Amer. J. Public Health 91, 1194-1199.

De Gaetano, A.T. and Allen, R.J.: 2002, 'Trends in twentieth-century temperature extremes across the United States', J. Clim. 15, 3188-3205.

Easterling, D.R., Meehl, G.A., Parmesan, C., Chagnon, S.A., Karl, T.R. and Mearns, L.O.: 2000, 'Climate extremes: Observations, modeling and impacts', Science 289, 2068-2074.

Ehhalt, D., Prather, M., Dentener, F., Derwent, R., Dlugokencky, E., Holland, E., Isaksen, I., Katima, J., Kirchhoff, V., Matson, P., Midgley, P. and Wang, M.: 2001, 'Atmospheric chemistry and greenhouse gases', in J. Houghton, Y. Ding, D. Griggs, M. Noguer, P. van der linden, X. Dai, K. Maskell and C. Johnson (eds.), Climate Change 2001: The Scientific Basis, Cambridge, U.K., Cambridge University Press.

Eheart, J.W. and Tornil, D.W.: 1999, 'Low-flow frequency exacerbation by irrigation withdrawals in the agricultural Midwest under various climate change scenarios', Water Resources Res. 35, 2237-2246.

Epstein, P.R.: 2001, 'West Nile virus and the climate', J. Urban Health-Bull. NY Acad Med. 78, 367-371.

Folland, C., Karl, T., Christy, J., Clarke, R., Gruza, G., Jouzel, J., Mann, M., Oerlemans, J., Salinger, M. and Wang, S.-W.: 2001, 'Observed climate variability and change', in J. Houghton, Y. Ding, D. Griggs, M. Noguer, P. van der linden, X. Dai, K. Maskell and C. Johnson (eds.), Climate Change 2001: The Scientific Basis, Cambridge, U.K., Cambridge University Press.

Githeko, A.K., Lindsay, S.W., Confalonieri, U.E. and Patz, J.A.: 2000, 'Climate change and vectorborne diseases: a regional analysis', Bull. WHO 78, 1136-1147.

Gordon, C., Cooper, C., Senior, C.A., Banks, H., Gregory, J.M., Johns, T.C., Mitchell, J.F.B. and Wood, R.A.: 2000, 'The simulation of SST, sea ice extents and ocean heat transports in a version of the Hadley Centre coupled model without flux adjustments', Climate Dynamics 16, 147-68.

Hanson, P.J. and Weltzin, J.F.: 2000, 'Drought disturbance from climate change: response of United States forests', Sci. Tot. Env. 262, 205-220.

IPCC (Intergovernmental Panel on Climate Change): 2000, in N. Nakicenovic (ed.), Special Report on Emissions Scenarios, Cambridge, Cambridge University Press.

Izaurralde, R.C., Rosenberg, N.J., Brown, R.A. and Thomson, A.M.: 2003, 'Integrated assessment of Hadley Center (HadCM2) climate-change impacts on agricultural productivity and irrigation water supply in the conterminous United States - Part II. Regional agricultural production in 2030 and 2095', Agric. Forest Meteor. 117, 97-122.

Jaffe, M.: 2001, Water Supply Management Options for Northeastern Illinois, Illinois-Indiana Sea Grant College Program, Grant \#C/ED-04-99, http://www.uic.edu/cuppa/upp/faculty/jaffe.

Johnson, D.W., Susfalk, R.B., Gholz, H.L. and Hanson, P.J.: 2000, 'Simulated effects of temperature and precipitation change in several forest ecosystems', J. Hydrology 235, 183-204.

Karl, T.R. and Knight, R.W.: 1997, 'The 1995 Chicago heat wave: How likely is a recurrence?', Bull. Am. Met. Soc. 78, 1107-1119.

Kling, G., Hayhoe, K., Johnson, L, Magnuson, J., Polasky, S., Robinson, S., Shuter, B., Wander, M., Wuebbles, D. and Zak, D.: 2003, Confronting Climate Change in Great Lakes Region, A Report of the Ecological Society of America and the Union of Concerned Scientists, Washington, D.C.

Knox, J.C. and Kundzewicz, Z.W.: 1997, 'Extreme hydrological events, palaeo-information and climate change', Hydro. Sci. J. 42, 765-779.

Knox, J.C.: 1993, 'Large increases in flood magnitude in response to modest changes in climate', Nature 361, 430-432.

Kunkel, K.E.: 2003, 'North American trends in extreme precipitation', Natural Hazards 29, 291-305.

Kunkel, K.E.: 2003, 'Sea surface temperature forcing of the upward trend in U.S. extreme precipitation', J. Geophys. Res. 108, 4020. 
Kunkel, K.E., Westcott, N.E. and Kristovich, D.A.R.: 2002, 'Assessment of potential effects of climate change on heavy lake-effect snowstorms near Lake Erie', J. Great Lakes Res. 28, 521-536.

Kunkel, K.E., Andsager, K., Conner, G., Decker, W.L., Hilaker Jr., H.J., Naber Knox, P., Nurnberger, F.V., Rogers, J.C., Scheeringa, K., Wendland, W.M., Zandlo, J. and Angel, J.R.: 1998, 'An expanded digital daily database for climatic resources applications in the Midwestern United States', Bull. Amer. Meteor. Soc. 79, 1357-1366.

Kunkel, K.E., Changnon, S.A., Lonnquist, C.G. and Angel, J.R.: 1990, 'A real-time climate information system for the Midwestern United States', Bull. Amer. Meteor. Soc. 71, 1601-1609.

Leggett, J., Pepper, W.J. and Swart, R.J.: 1992, 'Emission scenarios for the IPCC: An update', in J.T. Houghton, B.A. Callander and S.K. Varney (eds.), Climate Change 1992. The Supplementary Report to the IPCC Scientific Assessment, Cambridge, UK, Cambridge University Press, pp. 69-95.

Lehman, J.T.: 2002, 'Mixing patterns and plankton biomass of the St. Lawrence Great Lakes under climate change scenarios', J. Great Lakes Res. 28, 583-596.

Lemoine, N. and Bohning-Gaese, K.: 2003, 'Potential impact of global climate change on species richness of long-distance migrants', Conserv. Biol. 17, 577-586.

Lenters, J.D.: 2001, 'Long-term trends in the seasonal cycle of Great Lakes water levels', J. Great Lakes Res. 27, 342-353.

Lettenmaier, D.P., Wood, A.W., Palmer, R.N., Wood, E.F. and Stakhiv, E.Z.: 1999, 'Water resources implications of global warming: A US regional perspective', Climatic Change 43, 537-579.

Loehle, C. and LeBlanc, D.: 1996, 'Model-based assessments of climate change effects on forests: A critical review', Ecol. Modelling 90, 1-31.

Lofgren, B.M., Quinn, F.H., Clites, A.H., Assel, R.A., Eberhardt, A.J. and Luukkonen, C.L.: 2002, 'Evaluation of potential impacts on Great Lakes water resources based on climate scenarios of two GCMs', J. Great Lakes Res. 28, 537-554.

Martens, W.J.M.: 1998, 'Climate change, thermal stress and mortality changes', Soc. Sci. \& Med. 46, 331-344.

McCarthy, J.J., Canziani, O.F., Leary, N.A., Dokken, D.J. and White, K.S. (eds.): 2001, Climate Change 2001: Impacts, Adaptation, and Vulnerability, Cambridge, UK, Intergovernmental Panel on Climate Change, Cambridge University Press.

McGeehin, M.A. and Mirabelli, M.: 2001, 'The potential impacts of climate variability and change on temperature-related morbidity and mortality in the United States', Envir. Health Persp. 109, $185-189$.

McLaughlin, S. and Percy, K.: 1999, 'Forest health in North America: Some perspectives on actual and potential roles of climate and air pollution', Water and Soil Poll. 116, 151-197.

Meehl, G.A., Karl, T., Easterling, D.R., Chagnon, S., Pielke, R., Chagnon, D., Evans, J., Groisman, P.Y., Knutson, T.R., Kunkel, K.E., Mearns, L.O., Parmesan, C., Pulwarty, R., Root, T., Sylves, R.T., Whetton, P. and Zwiers, F.: 2000a, 'An introduction to trends in extreme weather and climate events: Observations, socioeconomic impacts, terrestrial ecological impacts, and model projections', Bull. Am. Met. Soc. 81, 413-416.

Meehl, G.A., Zwiers, F., Evans, J., Knutson, T., Mearns, L. and Whetton, P.: 2000b, 'Trends in extreme weather and climate events: Issues related to modeling extremes in projections of future climate change', Bull. Am. Met. Soc. 81, 427-436.

Meyer, J.L., Sale, M.J., Mulholland, P.J. and Poff, N.L.: 1999, 'Impacts of climate change on aquatic ecosystems functioning and health', J. Am. Water Res. Assn. 35, 1373-1386.

Mohseni, O. and Stefan, H.G.: 2001, 'Water budgets of two watersheds in different climatic zones under projected climate warming', Climatic Change 49, 77-104.

Mohseni, O., Erickson, T.R. and Stefan, H.G.: 1999, 'Sensitivity of stream temperatures in the United States to air temperatures projected under a global warming scenario', Water Resources Res. 35, 3723-3733. 
Mortsch, L.D. and Quinn, F.H.: 1996, 'Climate change scenarios for Great Lakes Basin ecosystem studies', Limnol. \& Oceanogr. 41, 903-911.

NAST (National Assessment Synthesis Team): 2001, Climate Change Impacts on the United States: The Potential Consequences of Climate Variability and Change, Report for the U.S. Global Change Research Program, Cambridge, UK. Cambridge University Press, 620 pp.

NCDC (National Climatic Data Center): 2003, U.S. Statewide Analysis, http://lwf.ncdc.noaa.gov/oa/climate/research/cag3/state.html (accessed August 2003).

Newman, J.E.: 1980, 'Climate change impacts on the growing season of the North American Corn Belt', Biometeorology 7, 128-142.

Paul, M.J. and Meyer, J.L.: 2001, 'Streams in the urban landscape', Ann. Rev. Eco. Sys. 32, 333-365.

Parry, M.L. and Carter, T.R.: 1989, 'An assessment of the effects of climate change on agriculture', Climatic Change 15, 95-116.

Pielke, R.A. and Downton, M.W.: 2000, 'Precipitation and damaging floods: Trends in the United States, 1932-97', J. Clim. 13, 3625-3637.

Pope, V.D., Gallani, M.L., Rowntree, P.R. and Stratton, R.A.: 2000, 'The impact of new physical parametrizations in the Hadley Centre climate model - HadAM3', Climate Dynamics 16, 123146.

Prentice, I., Farquhar, G., Fasham, M., Goulden, M., Heimann, M., Jaramillo, V., Kheshgi, H., Le Quéré, C., Scholes, R. and Wallace, D.: 2001, 'The carbon cycle and atmospheric carbon dioxide', in J. Houghton, Y. Ding, D. Griggs, M. Noguer, P. van der linden, X. Dai, K. Maskell and C. Johnson (eds.), Climate Change 2001: The Scientific Basis, Cambridge, U.K., Cambridge University Press.

Ramaswamy, V., Boucher, O., Haigh, J., Hauglustaine, D., Haywood, J., Myhre, G., Nakajima, T., Shi, G.Y. and Solomon, S.: 2001, 'Radiative forcing of climate change', in J. Houghton, Y. Ding, D. Griggs, M. Noguer, P. van der Linden, X. Dai, K. Maskell and C. Johnson (eds.), Climate Change 2001: The Scientific Basis, Cambridge, U.K., Cambridge University Press.

Reilly, J., Tubiello, F., McCarl, B., Abler, D., Darwin, R., Fuglie, K., Hollinger, S., Izaurralde, C., Jagtap, S., Jones, J., Mearns, L., Ojima, D., Paul, E., Paustian, K., Riha, S., Rosenberg, N. and Rosezweig, C.: 2003, 'US agriculture and climate change: New results', Climatic Change 57, 43-69.

Robinson, P.J.: 2001, 'On the definition of heat wave', J. Appl. Met. 40, 762-775.

Ruosteenoja, K., Carter, T.R., Jylha, K. and Tuomenvirta, H.: 2003, Future Climate in World Regions: An Intercomparison of Model-Based Projections for the New IPCC Emissions Scenarios, The Finnish Environment, Finnish Environment Institute (http://ipcc-ddc.cru.uea.ac.uk/asres/scatter_plots/scatter_plot_report.pdf, accessed 2003).

Sousounis, P.J., Scott, C.P.J. and Wilson, M.L.: 2002, 'Possible climate change impacts on ozone in the Great Lakes region: Some implications for respiratory illness', J. Great Lakes Res. 28, 626-642.

Southworth, J., Pfeifer, R.A., Habeck, M., Randolph, J.C., Doering, O.C., Johnston, J.J. and Rao, D.G.: 2002a, 'Changes in soybean yields in the Midwestern United States as a result of future changes in climate, climate variability, and $\mathrm{CO}_{2}$ fertilization', Climatic Change 53, 447-475.

Southworth, J., Pfeifer, R.A., Habeck, M., Randolph, J.C., Doering, O.C. and Rao, D.G.: 2002b, 'Sensitivity of winter wheat yields in the Midwestern United States to future changes in climate, climate variability, and $\mathrm{CO}_{2}$ fertilization', Climate Research 22, 73-86.

Southworth, J., Randolph, J.C., Habeck, M., Doering, O.C., Pfeifer, R.A., Rao, D.G. and Johnston, J.J.: 2000, 'Consequences of future climate change and changing climate variability on maize yields in the Midwestern United States', Agric. Ecosyst. \& Envir. 82, 139-158.

Strzepek, K.M., Major, D.C., Rosenzweig, C., Igleias, A., Yates, D.N., Holt, A. and Hillel, D.: 1999, 'New methods of modeling water availability for agriculture under climate change: The US Cornbelt', J. Am. Water Res. Ass. 35, 1639-1655. 
Thompson, I.D., Flannigan, M.D., Wotton, B.M. and Suffling, R.: 1998, 'The effects of climate change on landscape diversity: An example in Ontario forests', Env. Mon. Asst. 49, 213-233.

Trenberth, K.E.: 1999, 'Conceptual framework for changes of extremes of the hydrological cycle with climate change', Climatic Change 42, 327-339.

Watson, R.T., Zinyowera, M.C. and Moss, R.H. (eds.): 1998, The Regional Impacts of Climate Change, Intergovernmental Panel on Climate Change, Cambridge, UK, Cambridge University Press.

USCB (U.S. Census Bureau): 2002, Annual Survey of Manufactures - Geographic Area Statistics 2000, Washington DC: Department of Commerce.

USCB (U.S. Census Bureau): 2000, Statistical Abstract of the United States 1999 - Table 975 Manufactures - Summary by State, Washington, DC, USCB.

USCB (U.S. Census Bureau): 2003, Annual Population Estimates by State, http://eire.census.gov/popest/data/states/tables/ST-EST2002-01.php (accessed August 2003).

USDA (U.S. Department of Agriculture): 2000, Economic Research Service. State Facts. Value of receipts 2000, Washington, DC, USDA.

USEPA (U.S. Environmental Protection Agency): 2003, Inventory of U.S. greenhouse gas emissions and sinks: 1990-2001, EPA 430-R-03-004,

http://yosemite.epa.gov/oar/globalwarming.nsf/content/ ResourceCenterPublicationsGHGEmissionsUSEmissionsInventory2003.html (accessed August 2003).

Washington, W.M., Weatherly, J.W., Meehl, G.A., Semtner Jr., A.J., Bettge, T.W., Craig, A.P., Strand Jr., W.G., Arblaster, J.M., Wayland, V.B., James, R. and Zhang, Y.: 2000, 'Parallel climate model (PCM) control and transient simulations', Climate Dynamics 16, 755-74.

Winkler, J.A., Andresen, J.A., Guentchev, G. and Kriegel, R.D.: 2002, 'Possible impacts of projected temperature change on commercial fruit production in the Great Lakes region', J. Great Lakes Res. 28, 608-625.

Winstanley, D. and Changnon, S.A.: 1999, 'Long-term variation in seasonal, weather conditions important to water resources in Illinois', J. Am. Water Res. Ass. 35, 1421-1427.

Yogonathan, D. and Rom, W.N.: 2001, 'Medical aspects of global warming', Am. J. Industrial Medicine 40, 199-210. 
